\title{
Interpretasi Lingkungan Pengendapan Formasi Batuan Menggunakan Analisis Elektrofasies di Lokasi Tapak Puspiptek Serpong
}

\section{Interpretation of Depositional Environment of Rock Formations using Electrofacies Analysis in the Puspiptek Site, Serpong}

\author{
Heri Syaeful*, Adi Gunawan Muhammad \\ Pusat Teknologi Bahan Galian Nuklir-BATAN \\ Jl. Lebak Bulus Raya No. 09 Ps. Jumat, Jakarta 12440 \\ *E-mail: syaeful@batan.go.id
}

Naskah diterima: 27 April 2017, direvisi: 29 Mei 2017, disetujui: 31 Mei 2017

\begin{abstract}
ABSTRAK
Kegiatan karakterisasi material bawah permukaan penyusun pondasi tapak merupakan bagian dari studi tapak instalasi nuklir. Karakterisasi dilakukan dengan berbagai metode, diantaranya pemahaman tentang sistem pengendapan formasi batuan. Sebagai bagian dari metode interpretasi lingkungan pengendapan, analisis pemodelan fasies berdasarkan elektrofasies memberikan informasi yang cepat mengenai sistem pengendapan suatu formasi batuan. Metodologi yang digunakan adalah dengan interpretrasi log sinar gamma (log GR) menggunakan korelasi relatif antara variasi bentuk log dan fasies sedimentasi. Berdasarkan analisis diketahui Formasi Bojongmanik terbentuk pada lingkungan marine-lagoonal dengan pengaruh gelombang sangat rendah. Log GR yang menunjukan bentuk funnel, bergerigi dan simetris, mengindikasikan fasies shoreface, lagoon, dan tidal point bar. Arah sedimentasi, cekungan, dan suplai pada pengendapan sedimen Formasi Bojongmanik diinterpretasikan relatif ke utara. Formasi Serpong diendapkan pada sistem sungai bermeander dan tersusun atas endapan point bar, crevasse splay dan floodplain. Hasil analisis ini diharapkan dapat menjadi panduan dalam analisis lanjutan terkait karakterisasi material pondasi.
\end{abstract}

Kata kunci: studi tapak, lingkungan pengendapan, fasies, elektrofasies

\begin{abstract}
The activity of subsurface material composing site foundation characterization is part of nuclear installation siting study. Characterization conducted by several methods, such as understanding the depositional environment of rock formations. As a segment of depositional environment interpretation method, facies model analysis based on electrofacies provides quicker information on depositional system of rock formation. Methodology applied is gamma ray log (log GR) interpretation using relative correlation between log shape variation and sedimentation facies. Based on the analysis, Bojongmanik Formation was deposited on marine-lagoonal environment with very low wave influence. Log GR that shows shape of funnel, serrated, and symmetry, indicate shoreface, lagoon, and tidal point bar facies. The direction of sedimentation, basin, and supply of Bojongmanik Formation interpreted relatively to the north. Serpong Formation deposited on meandering river system, and composed of point bar deposit, crevasse splay, and floodplain deposit. The result of analysis is expected to be guidance in further analysis related to the characterization of foundation materials.
\end{abstract}

Keywords: siting, depositional environment, facies, electrofacies 


\section{PENDAHULUAN}

Kegiatan karakterisasi sebagai bagian dari studi tapak instalasi nuklir di Puspiptek Serpong dilakukan dengan berbagai macam metoda diantaranya logging geofisika secara in-situ di dalam lubang sumur geoteknik. Metoda logging geofisika sumur telah banyak dilakukan di dalam dunia geologi untuk mendapatkan parameter fisika yang sangat membantu dalam karakterisasi Formasi.

Logging geofisika dapat dijadikan dasar interpretasi tentang kondisi batuan yang merupakan proses akhir dari proses pengendapan dan diagenesa [1]. Secara ideal suatu rekaman logging akan mendatakan parameter Log Spontaneus Potential (SP) untuk mendatakan batas zona permeabel dan non-permeabel, Log Densitas untuk mengukur densitas, Log Neutron untuk mengukur jumlah pori dalam batuan, Log Resistivitas untuk membedakan fluida dalam formasi geologi, Log Sonik untuk mengukur kekakuan batuan, dan Log Sinar Gamma (Gamma Ray/GR) untuk mengukur intensitas radioaktif yang umumnya terdapat pada mineral lempung [2]. Secara lebih detil diuraikan bahwa log GR akan mengukur kandungan unsur potasium, uranium dan thorium yang kemungkinan dapat proporsional dengan kandungan lempung/ serpih dalam batuan [3]. Lebih jauh, penelitian tentang kandungan unsur radioaktif potasium, thorium dan uranium dalam endapan sedimen terumbu dan batugamping dapat memanfaatkan alat spektrometer gamma Exploranium GR-320 [4].

Tujuan analisis log GR adalah mengetahui fasies lingkungan pengendapan sebagai bagian dari pemahaman material pondasi pada kegiatan studi tapak instalasi nuklir [5]. Metoda analisis log GR untuk mengetahui fasies pengendapan ini efektif digunakan untuk mengevaluasi lingkungan pengendapan serpihan yang kaya organik pada lingkungan transisi [6], serta terkait endapan sungai untuk mengetahui kontrol siklus pada fasies sedimentasi [7][8]. Fasies sendiri diartikan sebagai aspek fisika, kimia atau biologi suatu endapan dalam kesamaan waktu [9]. Fasies dapat didefinisikan dalam berbagai skala yang berbeda, namun dalam studi yang ditujukan untuk interpretasi lingkungan pengendapan, fasies merupakan pembagian tubuh batuan menurut unit atau suatu aspek yang serupa [10]. Analisis fasies di lokasi tapak dilakukan dengan tujuan mengetahui posisi lingkungan pengendapan formasi batuan secara lokal di lokasi tapak terhadap kondisi regional pengendapan formasi batuan tersebut. Selain itu diharapkan dengan mengetahui kondisi dan lingkungan pengendapan dapat dijadikan panduan untuk analisis lanjutan karakterisasi material pondasi, diantaranya studi potensi lempung mengembang untuk material yang diendapkan pada lingkungan laut dangkal, potensi likuifaksi untuk material yang diendapkan pada lingkungan sungai.

\section{TEORI}

Korelasi merupakan suatu langkah penting dalam analisis fasies. Korelasi merupakan penghubungan titik-titik kesamaan waktu atau penghubungan satuansatuan stratigrafi dengan mempertimbangkan kesamaan waktu [9]. Prinsip dari korelasi stratigrafi adalah untuk menyamakan umur suatu lapisan sejenis dalam satu sumur dengan sumur lainnya. Dalam rangka mengetahui kesamaan lapisan tersebut dapat dilakukan dengan mengidentifikasi pola dari $\log$ sumur dalam hal ini log GR, kemudian dibandingkan dengan data inti bor sehingga didapatkan interpretasi yang lebih akurat. 
Lapisan dengan litologi sejenis dan memiliki umur geologi yang sama diasumsikan akan menghasilkan pola kurva log yang sama ketika di deteksi oleh alat logging sehingga kesamaan pada masing-masing sumur tersebut dapat ditarik garis korelasi.

Penentuan lingkungan pengendapan dapat dilihat dari bentuk kurva log GR. Bentuk tipikal log GR dengan beberapa fasies pengendapan secara umum dapat dilihat pada Gambar 1, dan terdiri dari:

1. Silindrik, menunjukkan sedimen tebal dan homogen yang dibatasi oleh pengisian alur (channel-fills) dengan kontak yang tajam. Silindrik merupakan bentuk dasar yang mewakili homogenitas dan ideal sifatnya. Bentuk silindrik diasosiasikan dengan endapan sedimen sungai menganyam, estuarine, pengisian alur pada submarine, eolian dune, dan tidal sand.

2. Bentuk corong (funnel shape) menunjukkan pengkasaran regresi atas yang merupakan bentuk kebalikan dari bentuk bell. Bentuk corong kemungkinan dihasilkan dari regresi dan progradasi seperti sub marine fan lobes, regressive shallow marine bar, barrier islands atau karbonat terumbu depan yang berprogradasi di atas mudstone, delta front (distributary mounth bar), crevasse splay, beach dan barrier beach (barrier island), strandplain, shoreface, prograding (shallow marine), shelf sands dan submarine fan lobes.

3. Bell Shape, menunjukkan penghalusan ke arah atas, kemungkinan akibat pengisian alur (channel fills). Bentuk bell dihasilkan oleh endapan point bars, tidal deposits, transgresive shelf sands (dominated tidal), sub marine channel dan endapan turbidit.

4. Simetrik, merupakan kombinasi antara bentuk bell-funnel. Kombinasi coarseningfinning upward ini dapat dihasilkan oleh proses bioturbasi. Selain tatanan secara geologi yang merupakan ciri dari shelf sand bodies, submarine fans dan sandy offshore bars.

5. Bergerigi (serrated), merupakan dasar untuk mewakili heterogenitas batuan. Bentuk bergerigi diasosiasikan dengan regresi alluvial plain, floodplain, tidal sand, shelf atau back barriers.

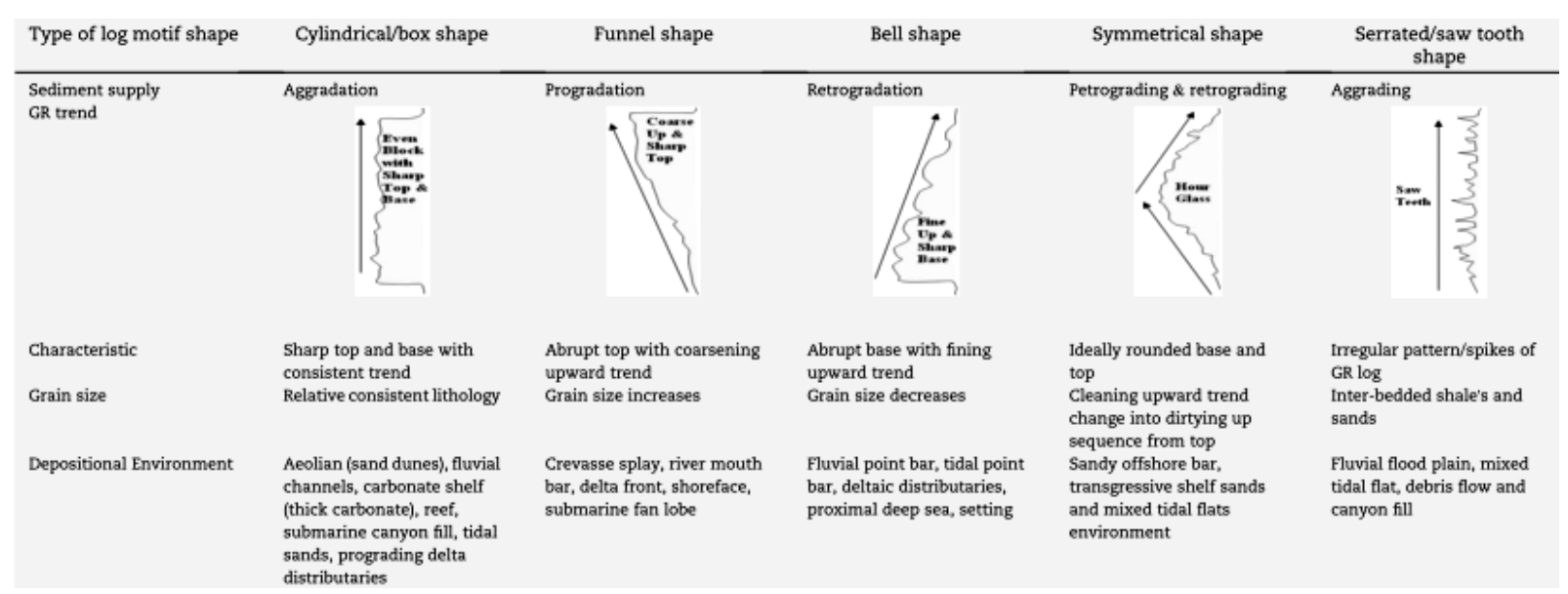

Gambar 1. Korelasi relatif antara variasi bentuk log dan fasies [2]. 


\section{METODOLOGI}

Pada pekerjaan studi tapak di Puspiptek Serpong, bersamaan dengan pengambilan inti bor untuk deskripsi visual dan contoh tanah/batuan untuk analisis laboratorium, dilakukan juga pengujian logging geofisika di lokasi tapak untuk pengambilan parameter $\log$ GR dan Densitas. Data log GR merupakan salah satu data utama di dalam korelasi. Log GR sangat bermanfaat untuk rekonstruksi tatanan pengendapan [11], analisis litologi dan analisis fasies [2][12]. Interpretasi fasies lingkungan pengendapan dilakukan berdasarkan karakteristik pola log GR seperti diperlihatkan pada Gambar 1. Studi lebih lanjut adalah membandingkannya dengan data inti bor dan singkapan batuan di sekitar lokasi penelitian untuk mendapatkan gambaran komprehensif tentang karakteristik fasies pengendapan formasi batuan di lokasi tapak.

\section{HASIL DAN PEMBAHASAN \\ Geologi Regional}

Secara elemen tektonik di Jawa Barat, lokasi penelitian terletak di antara Blok Banten dan Cekungan Jawa Barat-Laut (Gambar 2). Elemen tektonik Jawa Barat secara umum terdiri dari dua pola, yaitu Pola Utara-Selatan yang terdistribusi di bagian utara dan Pola Barat-Timur yang merefleksikan tren rejim tektonik kompresi muda [13].

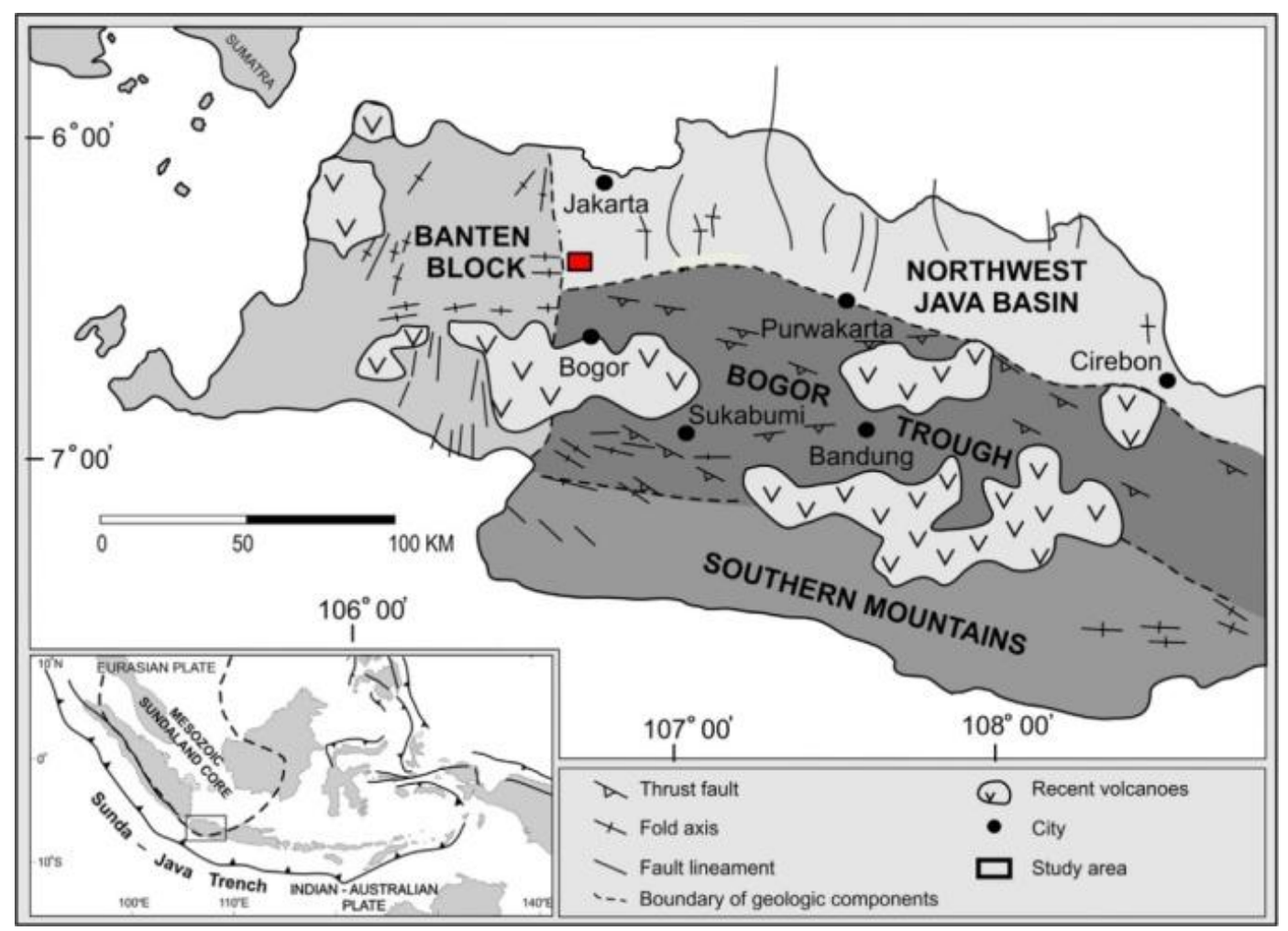

Gambar 2. Elemen tektonik Cekungan Jawa Barat [13].

Sejarah geologi lokasi penelitian secara regional diawali pada Kala Miosen Awal, dimana pada Miosen Awal, Jawa Barat mulai tergenang dan batugamping Formasi
Rajamandala yang terbentuk mulai Oligosen tertutup material volkanogenik [14]. Pada Miosen Tengah daerah Jawa Barat Utara merupakan lautan terbuka dan berbentuk 
paparan, sedangkan sebagian besar bagian selatan sudah berupa daratan dan sebagian laut transisi. Di daerah Banten diendapkan Formasi Bojongmanik pada kala ini. Perubahan fasies lingkungan pengendapan sebagai model dapat diamati secara baik di daerah Leuwiliang dimana Formasi Bojongmanik yang mempunyai lingkungan pengendapan laut transisi di bagian barat berubah menjadi Formasi Cibulakan dan Parigi yang diendapkan pada lingkungan laut terbuka di sebelah timur. Pada Miosen Akhir lautan di bagian utara Jawa Barat mulai mendangkal, dan daerah Banten diperkirakan sudah merupakan daratan. Pada kala Pliosen aktivitas gunungapi di Banten dimulai. Erupsi menyebabkan terbentuknya endapan Formasi Genteng yang berumur Pliosen sampai Plistosen Awal (Gambar 3) [15].

Formasi yang terdapat di daerah penelitian dari tua ke muda adalah Formasi Bojongmanik dan Formasi Serpong. Formasi Bojongmanik, tersusun oleh perselingan batupasir dan batulempung dengan sisipan batugamping, ketebalannya diperkirakan mencapai 1.000 m. Formasi Serpong, tersusun oleh perselingan konglomerat, batupasir, batulanau, batulempung dengan sisa tanaman, konglomerat batuapung, dan tuf batuapung. Berdasarkan kedudukan stratigrafinya menindih secara tidak selaras Formasi Bojongmanik dan Formasi Genteng, serta ditindih secara selaras oleh batuan vulkanik muda. Berdasarkan ciri-ciri batuan, struktur sedimen, dan bentuk sebarannya yang berada di sepanjang sungai, maka formasi ini diduga diendapkan pada sungai tua yang berpola menganyam dan bertanggul (levee), dan sebagian diendapkan pada lingkungan rawa (Gambar 4) [16].

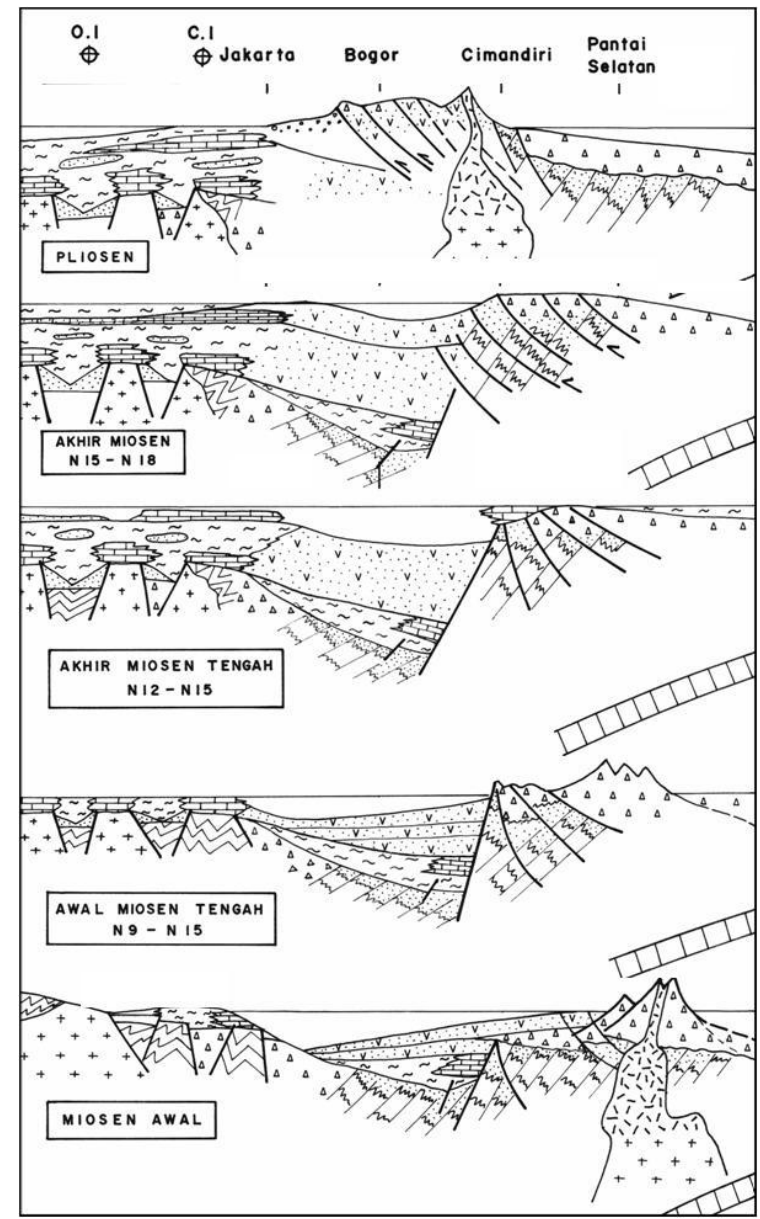

Gambar 3. Sejarah geologi lokasi penelitian secara regional [15]. 


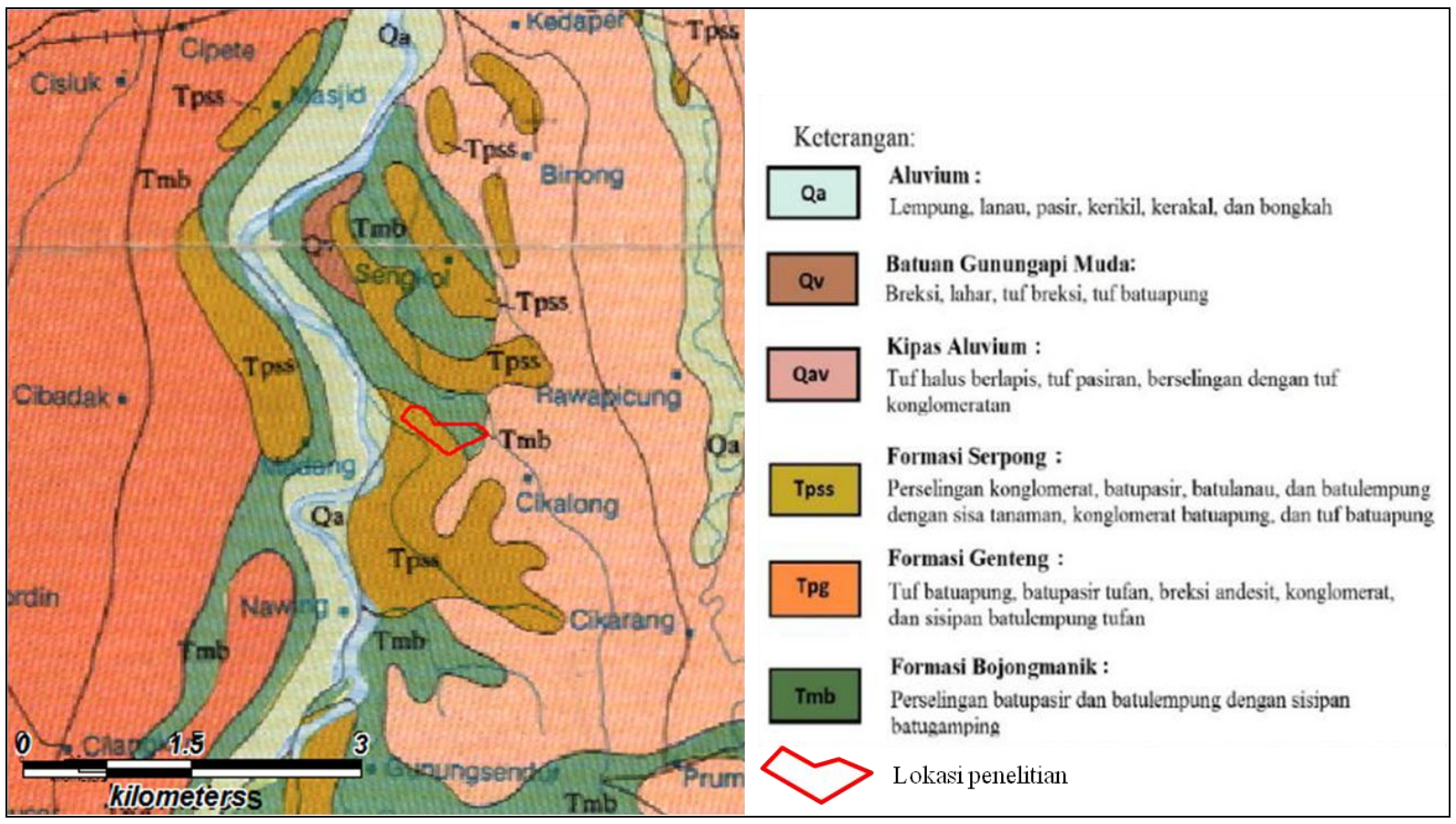

Gambar 4. Geologi regional lokasi penelitian [16].

\section{Analisis Elektrofasies}

Data yang digunakan dalam analisis elektrofasies adalah data log GR dan log litologi yang telah di koreksi posisi kedalaman batuannya berdasarkan data logging (Gambar 5). Berdasarkan deskripsi dan korelasi dengan data regional maka litologi di lokasi penelitian termasuk kedalam dua formasi, yaitu Formasi Serpong dan Formasi Bojongmanik. Litologi Formasi Serpong didominasi oleh batuan berwarna abu-abu terang, terdiri dari batupasir berfragmen dominan pumis, sebagian batugamping dan andesit. Terdapat pula lapisan tipis batulempung dan batulanau. Litologi Formasi Bojongmanik terdiri dari batulempung, batupasir, batulanau dengan dominasi warna abu-abu kehitaman dan sebagian abu-abu terang.

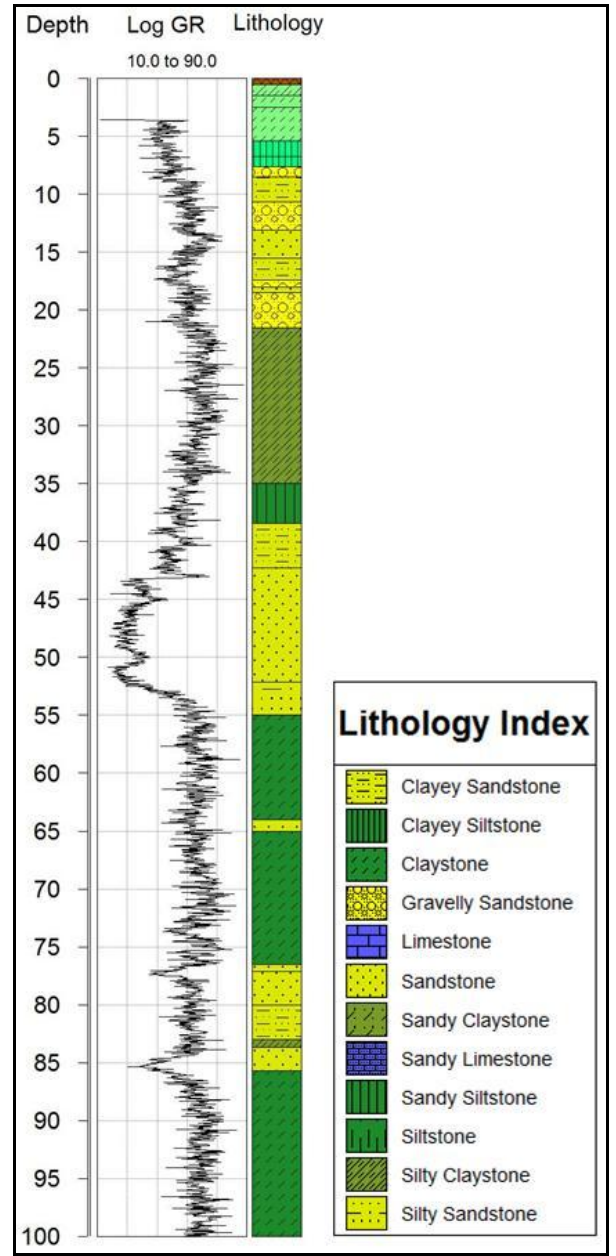

Gambar 5. Log GR dan log litologi DH-12. 
Berdasarkan perbandingan data logging dan data log litologi dari inti bor, maka data log GR memiliki karakteristik akurasi kedalaman yang lebih baik dikarenakan kemenerusan pengambilan data, tidak seperti inti bor yang diambil setiap interval kedalaman $3 \mathrm{~m}$. Selain berguna untuk koreksi kedalaman, perbandingan data litologi dan kurva log GR sangat membantu dalam interpretasi batas-batas perlapisan dengan mengambil patokan adanya perubahan pola kurva (defleksi kurva) yang merupakan tanda bahwa terdapat perubahan litologi yang dicirikan dengan perubahan distribusi butir dan kandungan lempungnya. Log GR juga merupakan indikator baik untuk ciri depositional break (tidak ada pengendapan), yang diperlihatkan dengan perubahan tajam dalam log GR. Kenampakan ini dapat terlihat jelas pada perubahan tajam log GR yang terdapat di sepanjang batas dua formasi yaitu Formasi Serpong dan Formasi Bojongmanik, yang diinterpretasikan merupakan kontak antara endapan marine - lagoonal dengan dataran banjir sistem sungai bermeander (Gambar 6).

Dalam rangka mendapatkan gambaran sebaran perkembangan fasies maka dalam korelasi dipilih titik-titik bor yang tersebar berarah utara - selatan dan barat - timur (Gambar 7). Dari data inti bor DH-08 secara umum menunjukkan bahwa Formasi Bojongmanik ini tersusun atas batuan yang berukuran butir halus (lempung - lanau), berwarna abu-abu gelap, dan diinterpretasikan terbentuk di lingkungan marine lagoonal dengan pengaruh gelombang sangat rendah.

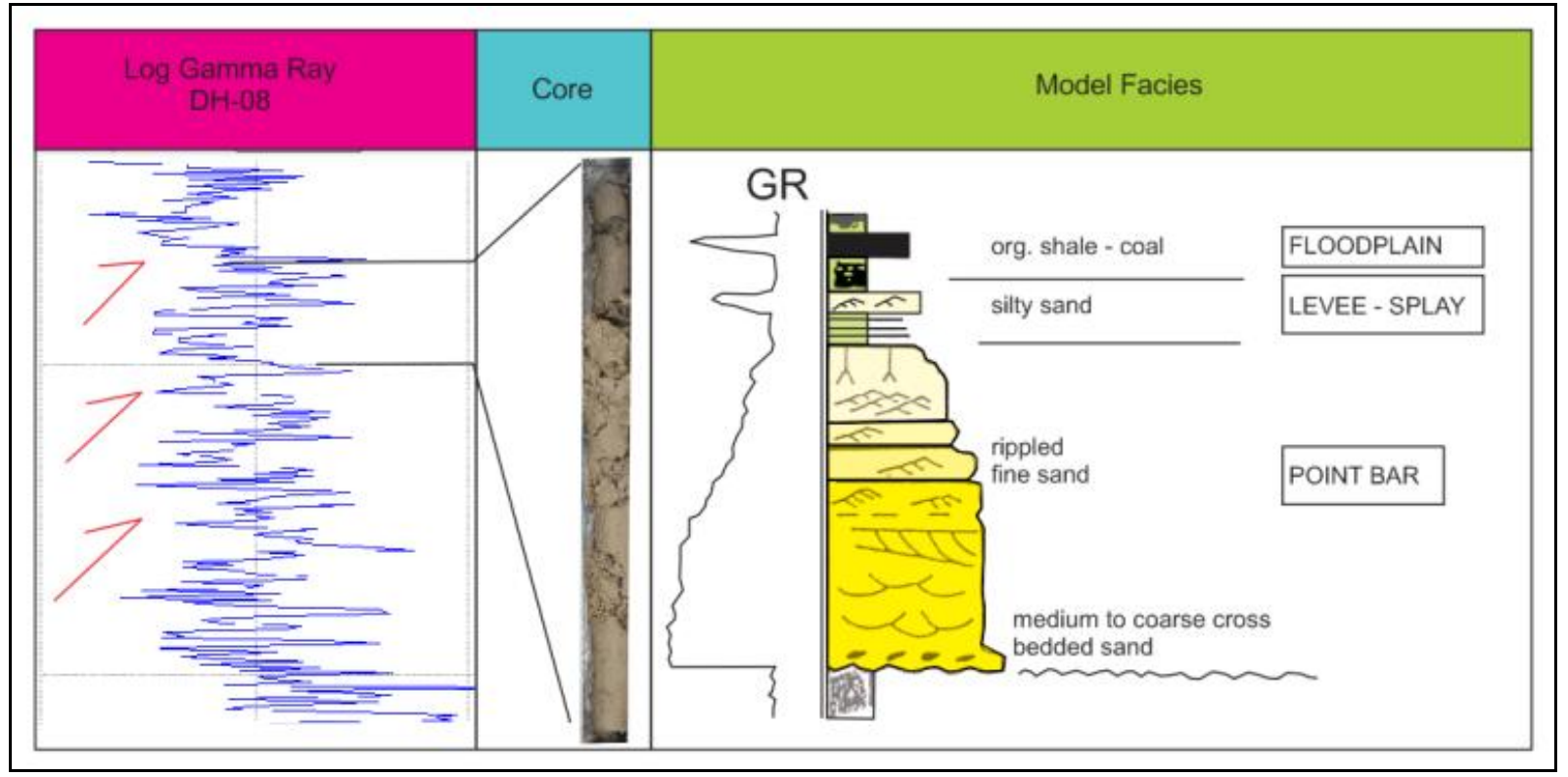

Gambar 6. Elektrofasies DH-08 dan interpretasi fasies pengendapanya. 


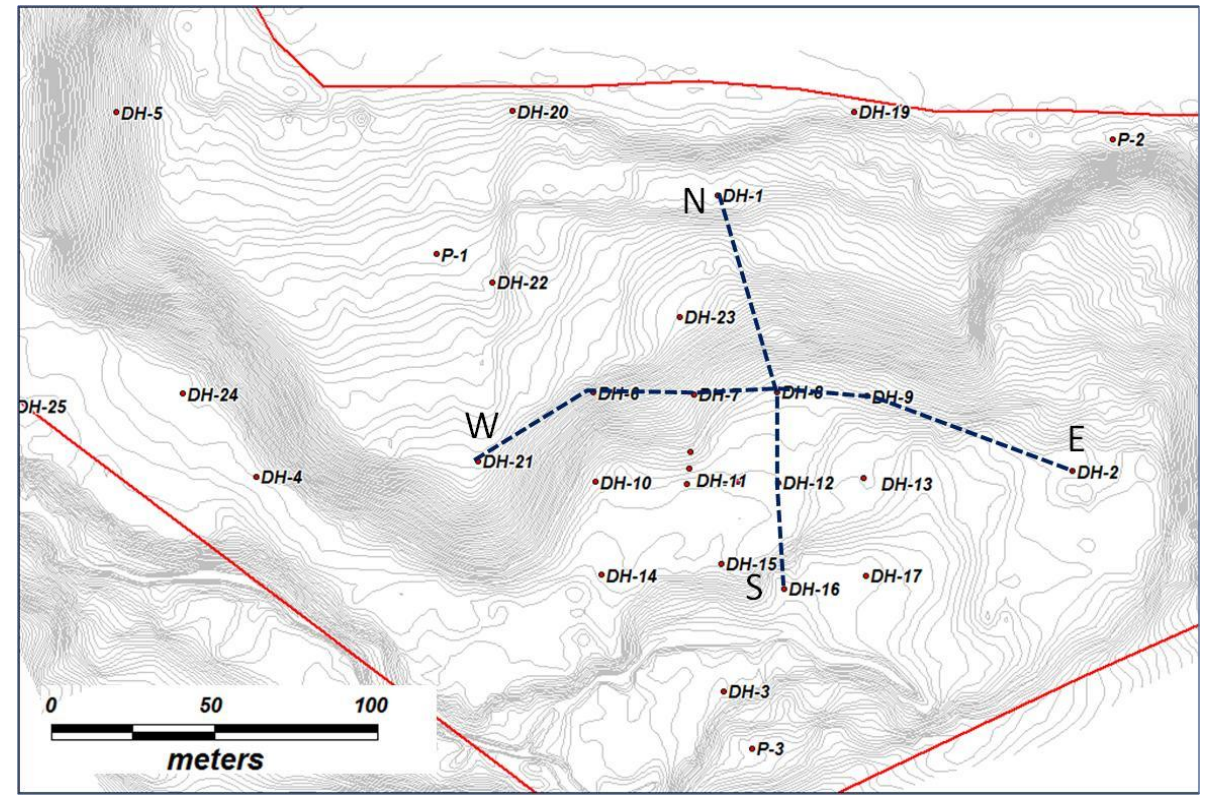

Gambar 7. Titik bor dan lintasan penampang.

Pada penampang utara-selatan, terjadi penebalan fasies marine atau lagoonal di bagian utara, sehingga dapat diinterpretasikan bahwa arah sedimentasi pada saat Formasi Bojongmanik terbentuk berarah relatif ke utara, sekaligus menunjukkan arah dari cekungan atau arah suplai sedimen. Bentuk log GR Formasi Bojongmanik dicirikan dari tua ke muda (Gambar 8 dan 9):

- log funnel yang diinterpretasikan sebagai sistem pengendapan pada shoreface atau barrier island yang merupakan pemisah antara laut terbuka dengan lagoon;

- log bergerigi (serrated) yang diinterpretasikan sebagai pengendapan lagoon;

- log simetri yang merupakan pengendapan tidal point bar;

- log bergerigi (serrated) yang merupakan pengendapan lagoon/back barrier.

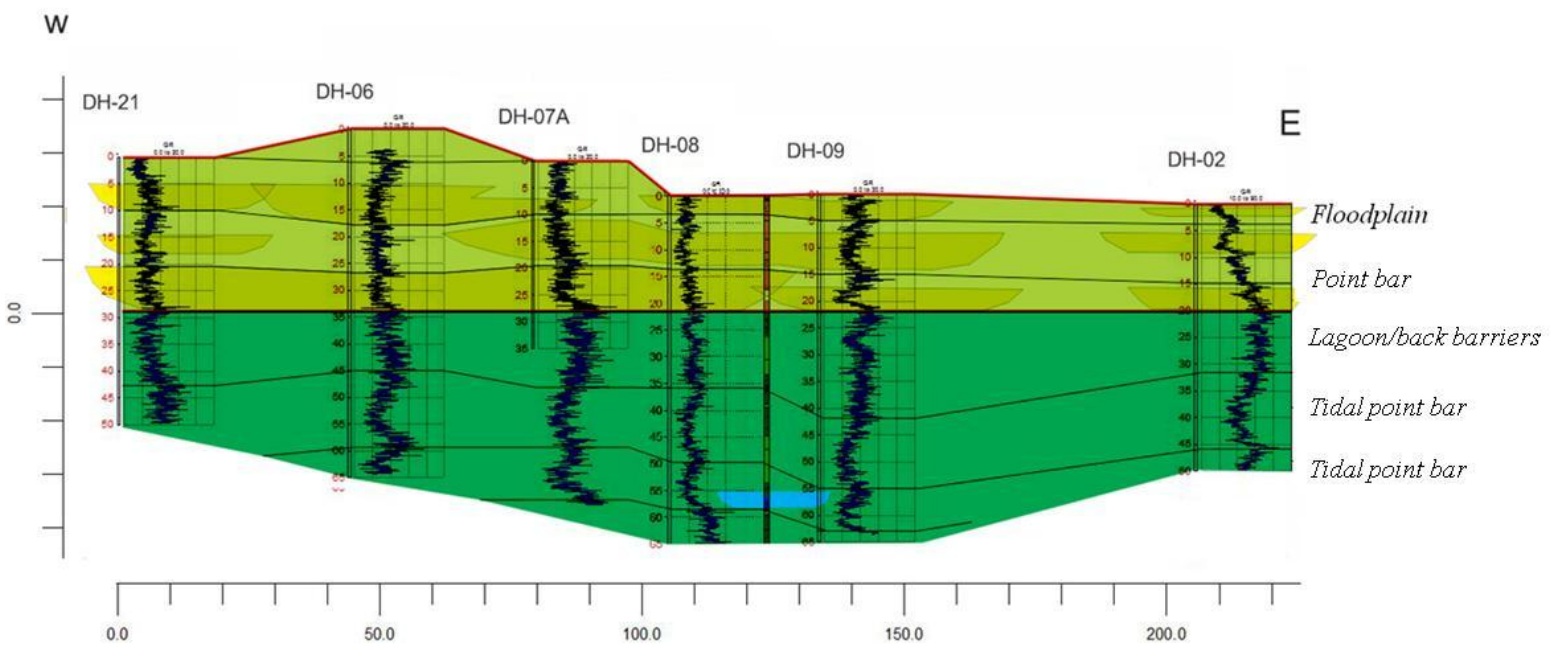

Gambar 8. Penampang barat-timur yang menunjukkan perubahan fasies berarah relatif tegak lurus pengendapan. 


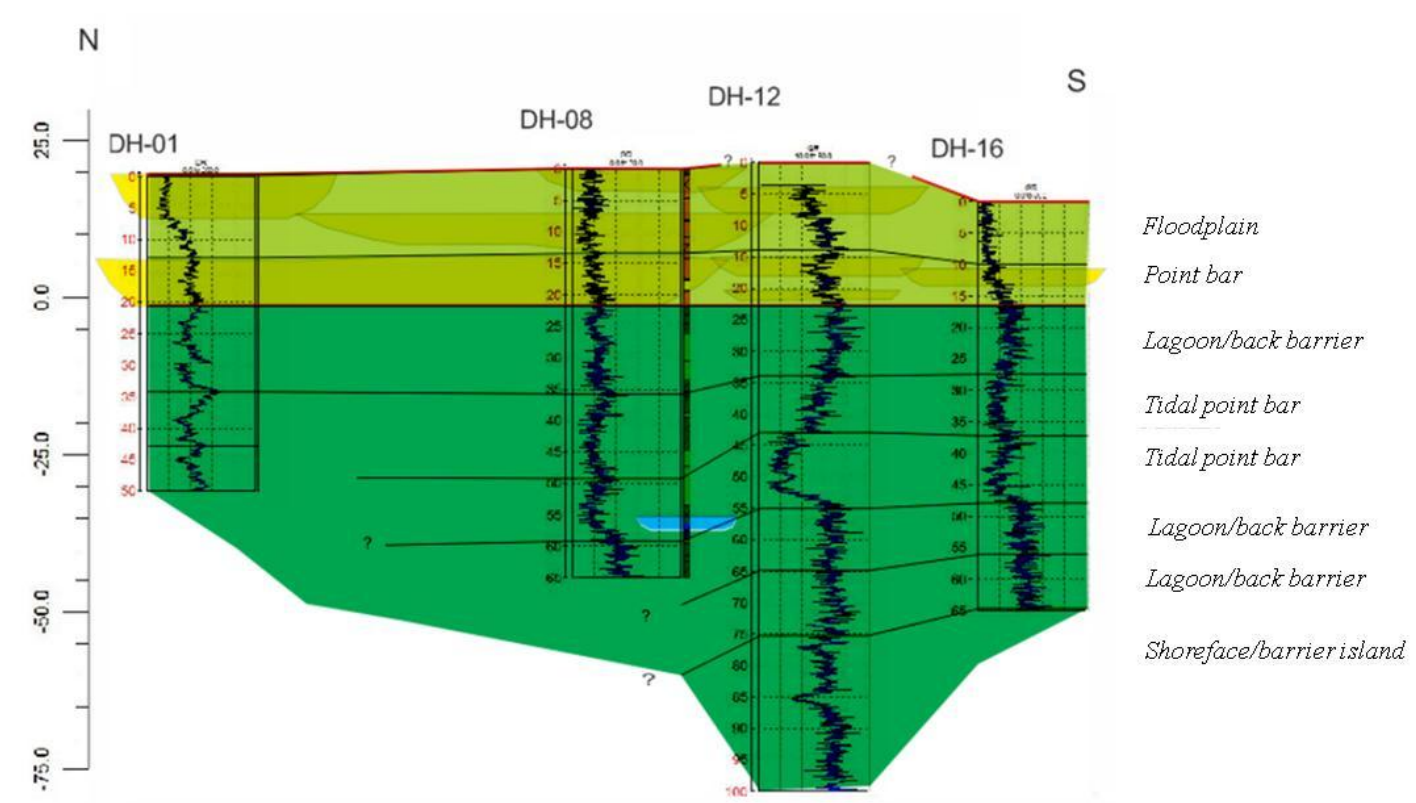

Gambar 9. Penampang utara selatan yang menunjukkan penebalan fasies lagoonal - marine ke arah utara.

Lingkungan pengendapan laut dangkal dapat dibagi kedalam tidal flat, lagoon, bioclastic bar, dan open marine (Gambar 10) [17]. Berdasarkan interpretasi elektrofasies Formasi Bojongmanik, terjadi perubahan lingkungan yang menunjukkan perubahan makin ke arah darat, dimana lingkungan berubah dari shoreface atau pada barrier island, menjadi lingkungan lagoon. Pada akhir dari sedimentasi lagoon diendapkan batugamping klastik, yang ditemukan pada lubang bor DH-08 dengan ketebalan 2,5 m dan diselingi lapisan batupasir lempungan. Selanjutnya terjadi pengendapan point bar pada lingkungan tidal flat. Sampai pada waktu tersebut dapat diinterpretasikan terjadi penurunan muka airlaut atau tektonik pengangkatan yang terjadi secara regional. Berdasarkan perubahan data perubahan level permukaan laut eustatik, terjadi penurunan muka airlaut sebanyak hampir $40 \mathrm{~m}$ dari pertengahan Miosen Tengah sampai pertengahan Miosen Akhir [13]. Data ini mendukung terjadinya perubahan lingkungan pengendapan yang semakin kearah darat di lokasi penelitian yang kemungkinan disebabkan penurunan level muka air laut. Pada tahap akhir pengendapan Formasi Bojongmanik yang dapat diinterpretasikan dari log, lingkungan kembali berubah menjadi lagoon, yang kemungkinan disebabkan terjadi peningkatan level muka air laut.

Setelah pengendapan Formasi Bojongmanik, terjadi penurunan relatif muka air laut atau tektonik pengangkatan, sehingga terbentuk suatu waktu tanpa pengendapan. Ketidakselarasan didefinisikan sebagai suatu permukaan yang memisahkan perlapisan lebih muda dari yang lebih tua, termasuk dibuktikan dengan adanya bukti erosi dan jeda pengendapan (hiatus) [10], biasanya ditunjukan oleh perubahan drastis dari fining upward menjadi coarsening upward atau sebaliknya. Sebagian ahli menyamakan antara sequence boundary dengan unconformity, sedangkan pengertian sequence boundary sendiri merupakan batas atas dan bawah satuan sikuen stratigrafi yang berupa bidang ketidakselarasan atau bidang-bidang keselarasan padanannya [9]. Diperkirakan 
kondisi tanpa pengendapan ini berlangsung di lokasi penelitian dari Miosen Akhir hingga Pliosen Awal. Kenampakan ini dalam log dicirikan dengan perubahan tajam dalam log GR yang mengindikasikan perubahan kontras dalam litologi atau lingkungan pengendapan.
Kenampakan ini bisa terlihat jelas pada Gambar 8 dan 9 berupa perubahan tajam log GR yang terdapat di sepanjang batas Formasi Serpong dan Formasi Bojongmanik. Periode ini sekaligus merupakan batas antara Formasi Bojongmanik dan Formasi Serpong.

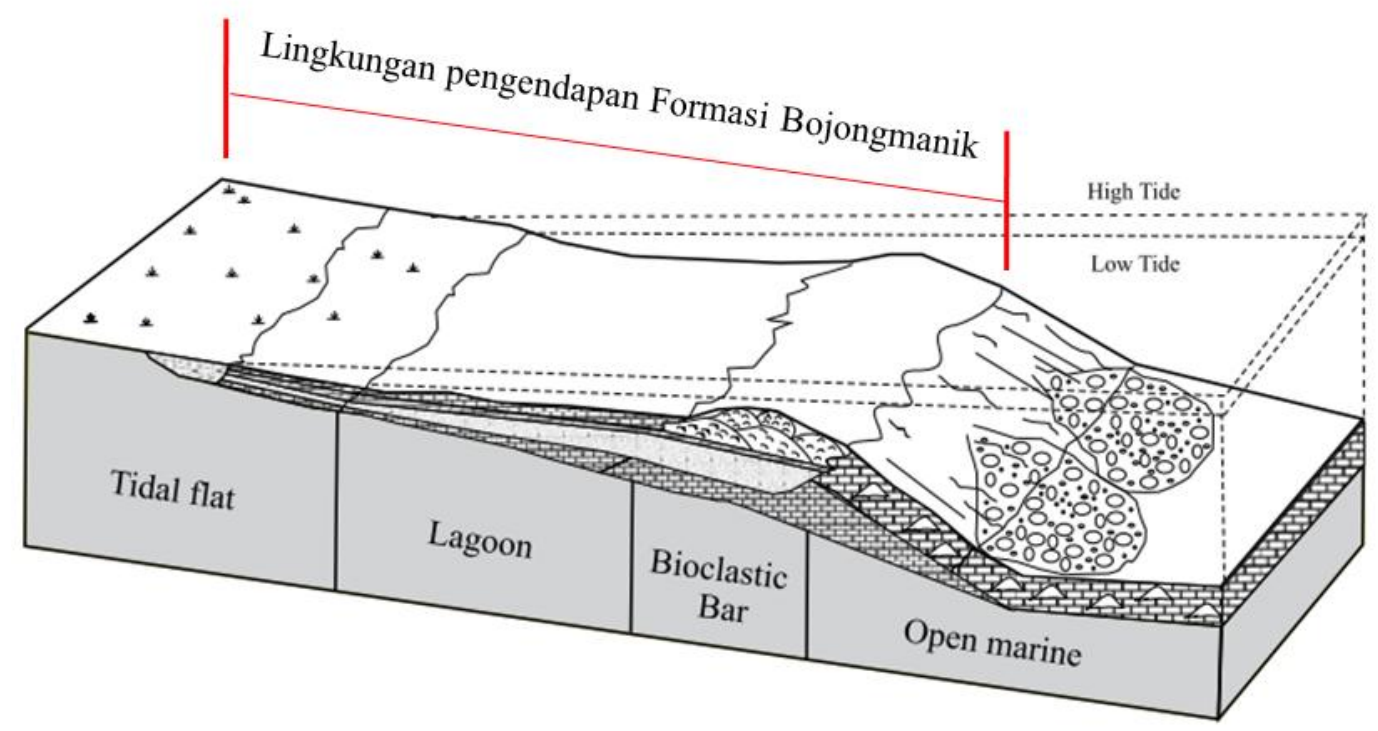

Gambar 10. Model pengendapan laut dangkal dan interpretasi lingkungan pengendapan Formasi Bojongmanik [17].

Berdasarkan singkapan batuan di sekitar lokasi penelitian, Formasi Bojongmanik tersusun atas batulempung abu-abu menyerpih dengan butiran kasar pecahan cangkang fosil. Pada beberapa lokasi ditemukan batugamping, berwarna putih kecokelatan, berkomposisi fragmen fosil (moluska dan koral), mineral karbonat, matriks berupa mikrokristalin kalsit dan detrital lempung. Kontak Formasi Bojongmanik dengan Formasi Serpong menunjukkan kontak ketidakselarasan berupa disconformity erosi batulempung oleh lensa point bar (Gambar 11).

Endapan batupasir Formasi Serpong secara ideal diamati pada lokasi penambangan pasir. Ketebalan Formasi ini mencapai lebih dari $20 \mathrm{~m}$. Terdapat setidaknya tiga kali siklus pengendapan endapan point bar dengan bagian bawah merupakan konglomerat berfragmen dominan pumis berukuran diameter 2-10 cm, dengan matriks batupasir kasar sampai halus. Struktur sediment berupa graded bedding, cross bedding, dan pararel lamination (Gambar 12). 


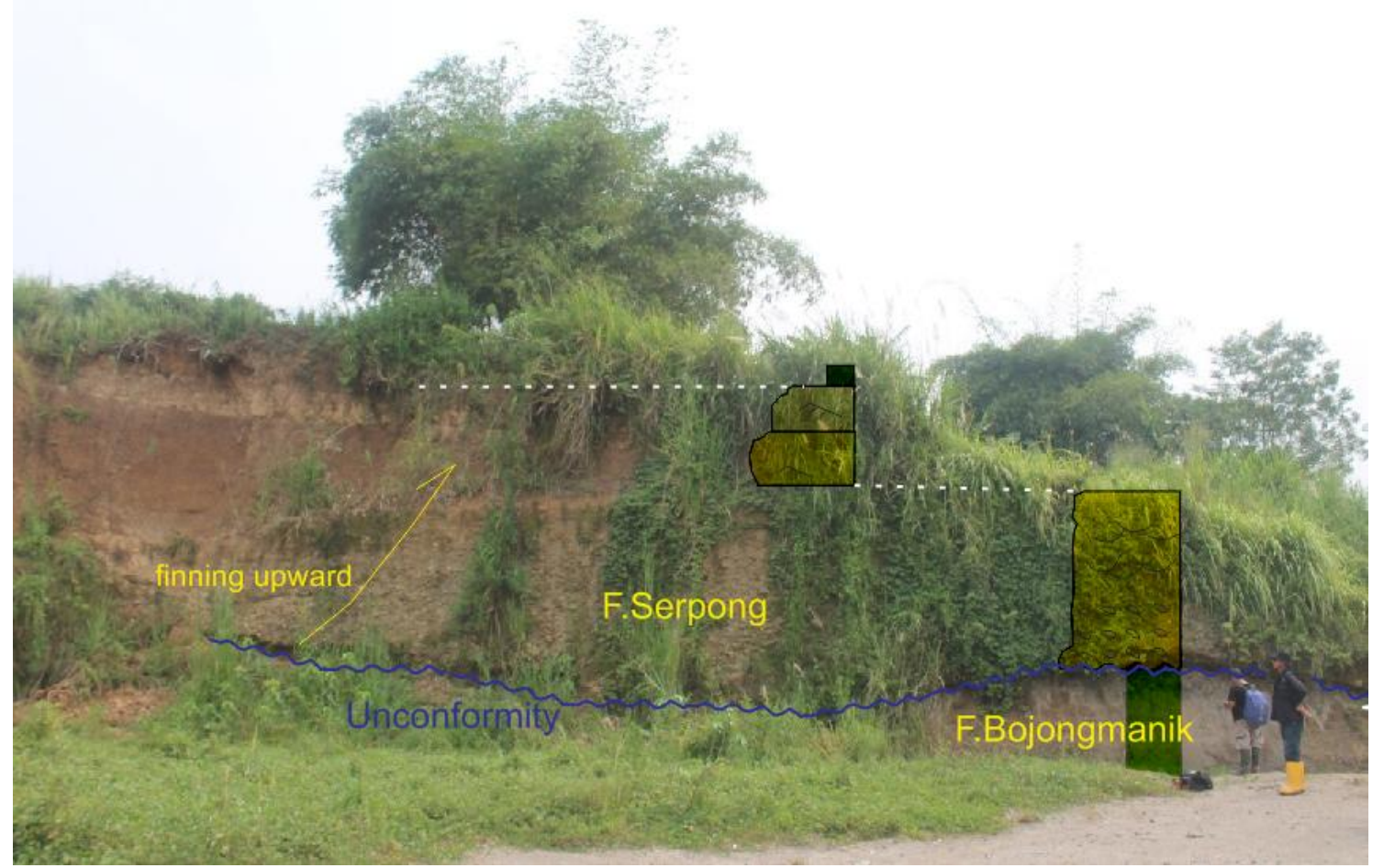

Gambar 11. Kontak Formasi Bojongmanik dan Formasi Serpong yang mengindikasikan kontak ketidakselarasan.

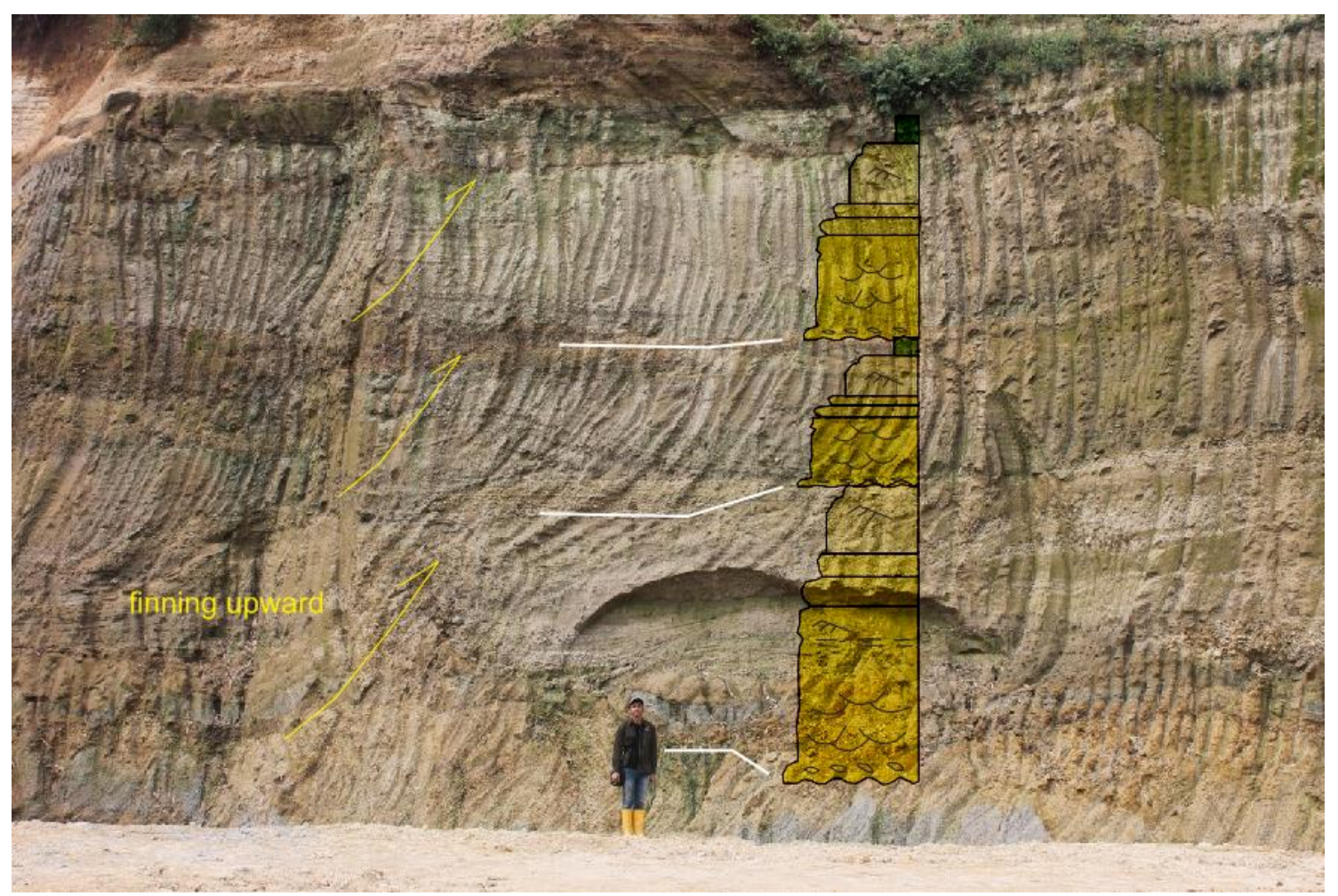

Gambar 12. Tipikal endapan point bar Formasi Serpong 
Analisis komparasi pada skala regional, Formasi Bojongmanik merupakan endapan khas Blok Banten. Formasi ini mempunyai umur yang berkisar antara N12 - N13 (Miosen Tengah) [15]. Bagian bawah Formasi Bojongmanik pada umumnya terdiri dari lempung, serpih dengan sisipan batugamping setebal $1,5-4 \mathrm{~m}$ yang mempunyai penyebaran cukup luas. Kemudian terdapat sisipan-sisipan batupasir berbutir halus sampai kasar. Struktur sedimen memperlihatkan urutan ke atas makin kasar dan bioturbasi. Ciri-ciri ini menunjukkan suatu endapan gosong pasir lautan (sand bar). Endapan tersebut di lokasi penelitian dapat diamati pada kedalaman 38 - $55 \mathrm{~m}$ di lubang bor DH-12 dimana terdapat lapisan pasir halus - sedang dengan bentuk log GR simetrik.

Struktur sedimen yang ditemukan pada Formasi Bojongmanik pada umumnya terdiri dari lapisan silang siur, flaser, dan gelembur gelombang serta laminasi paralel serta memperlihatkan penghalusan besar butir ke atas, yang menunjukkan ciri-ciri suatu endapan lagoon. Jenis endapan ini umum terdapat di bagian tengah Formasi Bojongmanik, tetapi di beberapa tempat dijumpai urutan-urutan konglomerat, batupasir kasar - halus, lanau dan di atasnya selang-seling batupasir halus dengan lempung, dan lapisan batubara tipis. Struktur sedimen terdiri dari lapisan bersusun, silang siur cekung, gelembur gelombang. Ciri-ciri ini menunjukkan suatu endapan gosong pasir sungai, sehingga Formasi Bojongmanik diinterpretasikan diendapkan pada lingkungan transisi, pada daerah pantai sampai lagoon [15], dan secara khusus di lokasi penelitian merupakan bagian lingkungan pengendapan marine - lagoonal. Studi perubahan muka air laut menyimpulkan muka airlaut berubah, transgresi pada Oligosen Akhir sampai Miosen Awal, dan regresi pada awal Miosen Tengah sampai akhir Pliosen [19], dicirikan dengan munculnya regressive sand bar, pada beberapa karakteristik log dilokasi penelitian.

Formasi Serpong di sekitar lokasi penelitian lebih banyak dikenal sebagai lapisan akuifer [18][19]. Satuan ini terdiri atas perselingan konglomerat, batupasir, batulanau, batu lempung dengan sisa tanaman, konglomerat batuapung dan tuf batuapung [16]. Berdasarkan kedudukan stratigrafinya yang menindih secara tidak selaras Formasi Bojongmanik dan Formasi Genteng dan ditindih secara tidak selaras oleh endapan kipas aluvial, diduga Formasi Serpong ini berumur Pliosen Akhir. Bila ditinjau dari ketidakadaannya fosil, struktur sedimen dan bentuk sebarannya disekitar sungai, maka Formasi Serpong ini diendapkan pada sungai tua yang berpola menganyam dan sebagian diendapkan pada lingkungan rawa [20]. Berdasarkan hasil analisis elektrofasies, lingkungan pengendapan Formasi Serpong di lokasi penelitian adalah sungai bermeander (meandering river). Tidak ditemukan bagian lingkungan pengendapan pola menganyam (braider river) di lokasi penelitian.

\section{KESIMPULAN}

Formasi Bojongmanik di lokasi penelitian tersusun atas batuan yang berukuran butir halus (lempung - lanau), berwarna abu-abu gelap, dan diinterpretasikan terbentuk di lingkungan marine lagoonal dengan pengaruh gelombang sangat rendah, log GR menunjukan bentuk funnel, bergerigi dan simetris, atau berupa fasies shoreface, lagoon, dan tidal point bar.

Perubahan fasies diperkirakan disebabkan penurunan muka air laut secara regional. Terjadi 
penebalan fasies di bagian utara sehingga diinterpretasikan arah sedimentasi, cekungan, dan suplai pada pengendapan sedimen Formasi Bojongmanik relatif ke utara. Formasi Serpong diendapkan pada sistem sungai bermeander, dan tersusun atas endapan point bar, crevasse splay dan floodplain. Hasil analisis ini diharapkan dapat menjadi panduan dalam analisis lanjutan terkait karakterisasi material pondasi, diantaranya studi terkait potensi lempung mengembang, potensi likuifaksi, daya dukung pondasi, dan lainnya.

\section{UCAPAN TERIMA KASIH}

Terimakasih penulis ucapkan kepada PTBGN-BATAN, dan kawan-kawan yang membantu dalam kegiatan lapangan selama pengambilan data diantaranya Pak Suharji, Dhatu Kamajati, dan Trisna Suntara.

\section{DAFTAR PUSTAKA}

[1] Y. Cui, G. Wang, S. J. Jones, Z. Zhou, Y. Ran, and J. Lai, "Prediction of diagenetic facies using well logs e A case study from the upper Triassic Yanchang Formation, Ordos Basin, China," Mar. Pet. Geol., vol. 81, pp. 50-65, 2017.

[2] A. Nazeer, S. Ahmed, and S. Hussain, "Sedimentary facies interpretation of Gamma Ray (GR) log as basic well logs in Central and Lower Indus Basin of Pakistan," Geod. Geodyn., vol. 7, no. 6, pp. 432-443, 2016.

[3] L. Rolon, S. D. Mohaghegh, S. Ameri, R. Gaskari, and B. Mcdaniel, "Using artificial neural networks to generate synthetic well logs," J. Nat. Gas Sci. Eng., vol. 1, pp. 118 133, 2009.

[4] C. Betzler, T. Pawellek, M. Abdullah, and A. Kossler, "Facies and stratigraphic architecture of the Korallenoolith Formation in North Germany (Lauensteiner Pass, Ith Mountains)," Sediment. Geol., vol. 194, pp. 61-75, 2007.

[5] International Atomic Energy Agency (IAEA), Geotechnical Aspects of Site Evaluation and Foundations for Nuclear Power Plants. Vienna, Austria, 2004.

[6] J. He, W. Ding, J. Zhang, A. Li, and W. Zhao, "Logging identification and characteristic analysis of marine-continental transitional organic-rich shale in the CarboniferousPermian strata, Bohai Bay Basin," Mar. Pet. Geol., vol. 70, pp. 273-293, 2016.
M. Benvenuti and S. Del Conte, "Facies and sequence stratigraphic modeling of a Upper Pliocene - Lower Pleistocene fluvial succession (Valdelsa Basin, central Italy)," Sediment. Geol., vol. 294, pp. 303-314, 2013.

[8] A. Roslin and J. S. Esterle, "Electrofacies analysis for coal lithotype profiling based on high-resolution wireline $\log$ data," Comput. Geosci., vol. 91, pp. 1-10, 2016.

[9] Ikatan Ahli Geologi Indonesia (IAGI), Sandi Stratigrafi Indonesia Edisi 1996. 1996.

[10] R. G. Walker and N. P. James, Facies model: response to sea level change. Geological Association of Canada, 1992.

[11] P. S. Momta and M. I. Odigi, "Reconstruction of the Depositional Setting of Tortonian Sediments in the Yowi Field, Shallow Offshore Niger Delta, Using Wireline Logs," Am. J. Geosci., vol. 6, no. 1, pp. 24-35, 2016.

[12] Q. K. Jadoon, E. M. Roberts, B. Henderson, T. G. Blenkinsop, R. A. J. Wüst, and C. Mtelela, "Lithological and facies analysis of the Roseneath and Murteree shales, Cooper Basin, Australia," J. Nat. Gas Sci. Eng., vol. 37, pp. 138-168, 2017.

[13] Abdurrokhim and M. Ito, "The role of slump scars in slope channel initiation: A case study from the Miocene Jatiluhur Formation in the Bogor Trough, West Java," J. Asian Earth Sci., vol. 73, pp. 68-86, 2013.

[14] B. Clements and R. Hall, "Cretaceous To Late Miocene Stratigraphic and Tectonic Evolution of West Java," in Proceedings of Indonesian Petroleum Association, 2007.

[15] S. Martodjojo, Evolusi Cekungan Bogor, Jawa Barat. ITB Bandung, 2003.

[16] T. Turkandi, Sidarto, D. Agustiyanto, and M. Hadiwidjojo, "Peta Geologi Lembar Jakarta dan Kepulauan Seribu, Jawa." Pusat Penelitian dan Pengembangan Geologi, Bandung, 1992.

[17] S. H. Vaziri, F. T. Fürsich, and N. Kohansalghadimvand, "Facies analysis and depositional environments of the Upper Cretaceous Sadr unit in the Nakhlak area , Central Iran," Rev. Mex. Ciencias Geol., vol. 29, no. 2, pp. 384 397, 2012.

[18] M. Fachri, Djuhaeni, L. M. Hutasoit, and A. M. Ramdhan, "Stratigrafi dan Hidrostratigrafi Cekungan Airtanah Jakarta," Bul. Geol., vol. 34, no. 3, pp. 169-190, 2002.

[19] R. M. Delinom, A. Assegaf, H. Z. Abidin, M. Taniguchi, D. Suherman, R. Fajar, and E. Yulianto, "The contribution of human activities to subsurface environment degradation in Greater Jakarta Area, Indonesia," Sci. Total Environ., vol. 407, no. 9, pp. 3129-3141, 2008. 
Interpretasi Lingkungan Pengendapan Formasi Batuan Menggunakan Analisis Elektrofasies di Lokasi Tapak Puspiptek Serpong

Oleh: Heri Syaeful dan Adi Gunawan Muhammad.

[20] Marjiyono, H. Suntoko, A. Soehaimi,

Yuliastuti, and H. Syaeful, "Kelas Soil Daerah

Sekitar Rencana Tapak Reaktor Daya

Eksperimental (RDE) Serpong Dari Data

Mikrotremor," J. Pengemb. Energi Nukl., vol.

17, no. 1, pp. 57-66, 2015. 